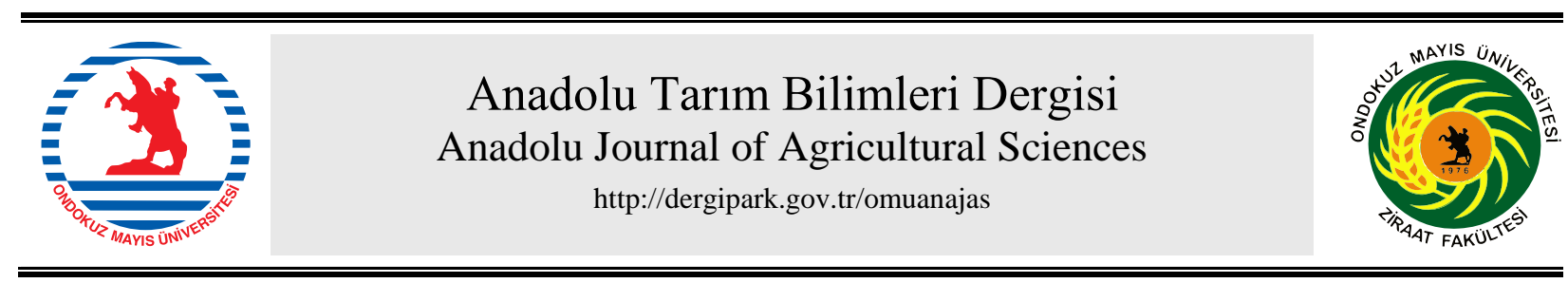

Araştırma/Research

Anadolu Tarım Bilim. Derg./Anadolu J Agr Sci, 36 (2021)

ISSN: 1308-8750 (Print) 1308-8769 (Online)

doi: 10.7161/omuanajas.789497

\title{
Hasandağ Volkanik Materyali Üzerinde Oluşan Toprakların Ayrışma Oranları ve Kütle Dengesi
}

\author{
Hasan Hüseyin Özaytekin ${ }^{\mathrm{a}}$ ๑Mert Dedeoğlu ${ }^{\mathrm{b} *}$ \\ ${ }^{a}$ Karamanoğlu Mehmetbey Üniversitesi, Teknik Bilimler Meslek Yüksekokulu, Organik Tarım Programı, Karaman, Türkiye \\ ${ }^{b}$ Selçuk Üniversitesi, Ziraat Fakültesi, Toprak Bilimi ve Bitki Besleme Bölümü, Konya, Türkiye
}

*Sorumlu yazar/corresponding author: mdedeoglu@selcuk.edu.tr

Geliş/Received 02/09/2020 Kabul/Accepted 10/10/2020

\begin{abstract}
ÖZET
Kayaçların yerkabuğu ile astenosfer arasındaki dolaşımı kayaç döngüsü olarak adlandırılmaktadır. Kayaç ve minerallerde oluşan bu değişim yerkabuğunun şekillenmesinde rol oynayan jeolojik süreçlerdir. Bu nedenle farklı doğal ortamlarda toprak oluşum süreçlerinin belirlenmesi, toprağın daha iyi tanımlanmasını ve anlaşılmasını sağlar. Bu çalışmanın amacı, volkanik ana materyal üzerinde oluşmuş dört volkanik toprak profilinde, toprak oluşumundan ve toprak sınıflandırmasından sorumlu fiziksel, kimyasal ve mineralojik özellikleri değerlendirmek ve bu toprakların pedojenik evrimini karşılaştırmalı olarak incelemektir. Bu amaçla seçilen 4 toprak profilinden horizon esasına göre alınan örneklerin mineralojik, jeokimyasal ve fizyokimyasal özellikleri belirlenmiştir. Kimyasal alterasyon indeksi (CIA), Kimyasal Ayrışma İndeksi (CIW), Parker ayrışma İndeksi (WIP) Üretkenlik İndeksi (PI), Plajiyoklaz alterasyon İndeksi (PIA), Bazlar / seskioksit oranı (Baz / $\mathrm{R}_{2} \mathrm{O}_{3}$ ) indeksi kullanılarak pedejenik süreçler ve ayrışma oranları hesaplanmıştır. Ayrıca incelenen toprakların pedojenik süreçlerini aydınlatmak amacıyla ana elementlerin kayıp, kazanç ve dönüşümleri Kütle dengesi modeli ile belirlenmiștir. İncelenen tüm profillerde ayrıșma indeksi değerleri jeolojik yaş ile uyumlu olarak dağılım göstermiştir. Bu da, söz konusu toprakların zamana bağlı olarak düşük yoğunluklu ayrışma ișlemlerine tabi tutulduğunu göstermektedir. Bölgedeki dominat toprak olușturma süreçleri; : 1 . Solumdan bazik katyonlarının ve Al'ın yıkanması ve kaybı, 2. Demir ve alüminyumun kumdan ve silt boyutundaki fraksiyonlardan ikincil kil ve kristalize Fe minerallerine dönüşümü şeklinde gerçekleşmiştir. Pedonlardaki fiziksel, kimyasal ve mineralojik özelliklerin benzer ve sinırlı varyasyonu ve pedonlar arasındaki ayrıșma indekslerinin ve kütle dengesi modelinin çok sınırlı varyasyonu, pedonların benzer aşınma seviyelerine sahip olduğunu göstermektedir. Elde edilen sonuçlar, incelenen alandaki toprak oluşumunu rakım, yöney, yükselti eğimi ve zaman tarafından belirlendiğini göstermektedir.
\end{abstract}

Weathering rates and mass balance of soils developed on hasandağ volcanic materials

\section{ABSTRACT}

The circulation of rocks between the earth's crust and the asthenosphere is called the rock cycle. This change in rocks and minerals is the geological processes that play a role in the shaping of the earth's crust. Therefore, the determination of soil formation processes in different natural environments allows soil to be defined better than that. The objectives of the present work were to assess the physical, chemical and mineralogical characteristics and pedolojical processes responsible for soil genesis and soil classification of four volcanic soil profiles derived volcanic parent material and to study and compare the pedogenic evolution of these soils. To achieve this, soil samples were collected from the horizons to investigate their mineralogical, geochemical and physiochemical properties. Chemical alteration Index (CIA), (CIW), Parker weathering, Index (WIP), Product Index (PI), plagioclase
Anahtar Sözcükler: Ayrışma oranı Hasandağ 1 Kütle dengesi Toprak oluşumu Volkanik materyal 
Alteration Index (PIA), Bases / sesquioxide Rate (Base $\left./ \mathrm{R}_{2} \mathrm{O}_{3}\right)$ are used to compare the pedogenic processes as a case study. The pedogenic processes were also evaluated used to Mass-balance analysis to quantify elemental losses, gains and transformations for soils studied. Weathering index values were distributed in harmony with the geological age in all studied profiles. This shows that the soils in question are subjected to low intensity decomposition processes depending on time. Dominat soilforming processes include 1. desilication and loss of base cations and $\mathrm{Al}$ from the solum, 2. transformation of iron and aluminum from sand and silt-size fractions to secondary clay and crystalline Fe minerals. The similar and limited variation of physical, chemical and mineralogical properties in pedons, and very limited variation of the weathering indexes and mass balance pattern across pedones indicate that pedones have similar levels of weathering. Our results imply that the rate of elemental mass-balance changes is determined by factors influencing its leaching altitude, facing sites, elevational gradient and time in the studied area.

\section{Giriş}

Volkanik alanlar etrafındaki araziler patlamalardan sonra piroklastik akıntılar, volkanik küller, lahar çökelleri, lav akıntıları gibi birçok volkanik materyal ile kaplanırlar. Bu volkanik materyaller değişik boyutta feldspat, kuvars, hornblent, hipersten, biyotit, ojit, magnetit gibi mineral gruplarından birçok mineral ve volkanik cam içerir. Tefranın birikme işlemlerinden sonra toprak oluşumu başladığı andan itibaren, materyalin elementel ve mineralojik kompozisyonu değişime uğrar ve volkanik kül toprakları veya andisol olarak isimlendirilen benzersiz özelliklere sahip topraklar oluşur. Volkanik materyalin özelliklerine bağlı olarak, ayrışma boyunca toprak ortamına birçok besin elementi bu süreç boyunca sağlanmaktadır. Topraklar oluşum faktörlerinin ortak etkisi sonucu gelişirler (Jenny, 1941). Toprakların, toprak oluşumu için geçen zamana bağlı olarak değişimleri oldukça farklılık gösterir. Bu değişimler içinde minerallerin parçalanması ve elementlerin jeokimyasal değişimleri ve toprak bitki su sistemindeki döngüleri gibi konular yer alır. Toprakların bireysel ayrışma oranları, toprak özelliklerindeki değişimler ve çevre şartlarındaki farklılıklar nedeniyle çok değişkendir. Toprak oluşumu için geçen zaman toprakların özelliklerini etkiler ve onların ayrışma oranlarını belirler. Bu etki zamanla fiziksel, kimyasal ve mineralojik özelliklerin değişimi veya değişik sayılarda horizon farklılaşması gibi olaylarla ortaya çıkar. Oluşumun erken evrelerinde toprakların kimyasal yapısı ana materyal tarafından kontrol edilirken, olgun toprakların kimyasal özellikleri ayrışma ortamının etkilerini yansıtır. Zamanla vejetasyon, topografya ve özellikle iklimin etkisiyle ortaya çıkan Pedojenik süreçler ile toprak kompozisyonu ana materyalden farklılaşır. Bu farklılaşma başlangıç olarak elementlerin toprak profili içinde yeniden dağılımı, horizonlaşma ve son olarak da peyzajda bu dağılıma bağlı olarak toprak tiplerinin farklılaşması olarak sonuçlanır. (Jenkins ve Jones, 1980). Ancak toprak oluşumu için geçen zaman aynı olsa bile diğer toprak yapan faktörlerin etkisi ile toprak morfolojisi ve fiziko-kimyasal özellikleri farklılık gösterebilir.

Toprakların ve kayaçların jeokimyasal olarak ayrılarak karakterize edilmesinde ve yine toprakların ayrışma süreçlerinin sayısallaştırılarak incelenmesinde kullanılan bir yöntem de ayrışma indisleridir (Nesbitt, 1979; Carr ve ark. 1980; Chesworth ve ark, 1981; White 1983; Nesbitt ve Wilson 1992 ). Ayrışma indisleri geleneksel olarak ana element oksitlerinin molekül oranlarının kullanıldığ değişik formüller ile hesaplanır. Ayrışma boyunca ana element oksitlerinin sitokiometrik olarak değişimi indeks değerlerinde ortaya çıkar. Her bir oksidin moleküler oranları söz konusu oksitlerinin ağırlık yüzdesi kullanılarak kolaylıkla hesaplanabilir. Bazen alterasyon indeksleri olarak da adlandırılan kimyasal ayrışma indeksleri genellikle ayrışan profilleri karakterize etmek için kullanılır. Kimyasal ayrışma indeksleri, her numune için toplam ana element oksit kimyasını tek bir değerde birleştirir. Ayrışma indeksleri tipik olarak, toprak profilinde derinliğe karşı indekslerin grafiği çizilerek uygulanır ve ana kayanın olası artan (veya azalan) ayrışması ile toplam element kimyasındaki değişikliklerin görsel bir temsilini sağlar. Derinlikle birlikte ayrışma indeksindeki değişiklikler genellikle kademeli veya sürekli olmakla birlikte granit gibi homojen ana kayalar için sabit ve sistematiktir (Sutton ve Maynard, 1992). Bu da başlangıçta homojen bir ana malzeme üzerinde ayrışma ilerledikçe elementlerin sürekli yıkanmasını yansıtır. Toprak oluşum süreçlerinin herhangi bir faktör tarafından bölgesel olarak etkilendiği ve değiştirildiği durumlarda ayrışma ve toprak oluşum hızlarının tahmin edilmesi için güvenilir yöntemlere ihtiyaç vardır. Doğal sistemlerdeki ayrışma reaksiyonlarını tanımlamanın en doğru yolunun normalde hesaplama temeli olarak jeokimyasal kütle dengesi denklemlerinin kullanılabileceği birçok çalışmada önerilmiştir. (Bricker ve ark., 2003, Owens ve Watson, 1979, Wakatsuki ve Rasyidin, 1992). Kütle dengesi modeli toprak oluşumu süresi boyunca herhangi bir element için kayıp ve kazanç ve dönüşümler sonucu ortaya çıkan miktarlarının sayısallaştırılmasında kullanılan bir metottur (Brimhall ve Dietrich, 1987).

Orta Anadolu'da yarı kurak iklim şartlarında oluşan volkanik materyalin ayrışma ürünleri yağışlı alanlarda oluşanlardan daha farklıdır ve toprak oluşumu söz konusu ortamlarda tam olarak ortaya konmamıştır. Bu çalışmada Aksaray sınırları içinde yer alan ve Hasan Dağı volkanik materyali üzerinde oluşan toprakların fiziksel, kimyasal özellikleri, ayrışma ürünleri ve pedogenetik süreçler araştırılmış, ayrışma oranları çeşitli ayrışma indeksleri ve açık sistem kütle taşınımı yöntemiyle belirlenmeye çalışılmıştır. 


\section{Materyal ve Yöntem}

\subsection{Coğrafi konum}

Çalışma alanını Konya'nın kuzey doğusunda bulunan Aksaray ili sınırları içinde yer alan Kuvarterner yaşlı Hasandağı volkaniklerinin çıkarmış olduğu ana materyal üzerinde oluşmuş topraklar oluşturmaktadır. Hasan Dağ1 Aksaray-Niğde İl sınırı arasında, Aksaray'ın yaklaşık $30 \mathrm{~km}$ güney-güneydoğu yönünde simetrik bir huni şeklinde yükselen, güneyde $38^{\circ}-01^{\prime} \mathrm{K}$ ve kuzeyde $38^{\circ}-11^{\prime} \mathrm{K}$ paralelleri ile batıda $34^{\circ}-02^{\prime} \mathrm{D}$ ve doğuda $34^{\circ}-17^{\prime} \mathrm{D}$ meridyenleri arasında bulunmaktadır. Hasan Dağı; İç Anadolu Bölgesinin Erciyes Dağı'ndan (3917 m) sonra gelen en yüksek ikinci sönmüş volkanik dağıdır.

\section{2 Íklim}

Çalışma alanı Orta Anadolu'da yarı kurak karasal iklim etkisi altındadır. İklim özellikleri bakımından Hasan Dağı, çevresindeki alçak sahalara göre yazları serin, kışları oldukça soğuk ve daha yüksek miktarlarda yağış alan ve yağışın büyük kısmının kar şeklinde düştüğü "Dağ iklimi” şartlarına sahip bir kütledir. Hasandağında yıllık ortalama yağış $321.3 \mathrm{~mm}$, yıllık buharlaşma ise $1317.9 \mathrm{~mm}$ 'dir. Yıllık ortalama sıcaklık $9.68{ }^{\circ} \mathrm{C}, 50 \mathrm{~cm}$ 'deki ortalama toprak sicaklığ $13.59^{\circ} \mathrm{C}$ dir.

\subsection{Jeoloji}

Orta Anadolu'da Aksaray ve Niğde arasında bulunan Hasandağı içinde çok sayıda volkan konilerinin, kraterlerin, tüf örtülerinin ve lav akıntılarının yer aldığı $50 \mathrm{~km}$ uzunlukta ve ortalama $20 \mathrm{~km}$ genişlikte bir volkan alanı olup (Ketin, 1983), volkanizma bu bölgede Orta Miyosende başlamış ve çeşitli evrelerle Kuvaterner sonuna değin etkin olmuştur. Genellikle ignimbirit, kül, lapilli, tüf ve aglomera gibi piroklastiklerle andezit, bazalt, riyodasit ve hornblent-piroksen bazaltlar ve olivin bazalt türündeki lavlardan meydana gelen volkanikler Hasan Dağı volkanının as1l materyallerini oluşturur (Emre, 1991; Aydar ve Gourgaud, 1998, Pasquare, 1966).

\subsection{Toprak profil noktalarının belirlenmesi ve örneklerin alınması}

Çalışma alanı 1/100.000 ölçekli toprak haritaları (Anonim, 1992), ve jeoloji haritası (Anonim, 1962) ve bölgeye ait geçmiş çalışma raporları kullanılarak incelenmiş daha sonra 1/25.000 ölçekli topoğrafik harita paftaları ile bölge dolaşılmış ve elde edilen veriler ışığında, çalışma alanında seçilen 4 adet profil açılmıştır.

Toprak profillerinin morfolojik tanımlamalarında Soil Survey Manual (1993) tarafindan belirtilen usuller esas alınmıştır. Horizonların tanımı ve adlandırılması ise Soil Survey Staff (1999)'a göre yapılmıştır. Laboratuvar analizleri için açılan profillerden horizon esasına göre bozulmuş ve bozulmamış toprak örnekleri alınmış, örneklere iz element bulaşması olmaması için plastik malzeme kullanılarak toplanmış ve temiz plastik torbalarda laboratuvara taşınmıştır. Laboratuvara getirilen örnekler kurutularak $2 \mathrm{~mm}$ 'lik elekte elenmiş ve analizlerde kullanılmak üzere plastik saklama kaplarında depolanmıştır.

\subsection{Fiziksel ve kimyasal analiz metotlar}

Toprak örneklerinde parça büyüklüğ̈̈ dağılımı (Bouyoucous, 1951), 1:2.5 toprak saf su süspansiyonunda EC (U.S.Salinity Lab. Staff, 1954) ve pH tayini (Soil Survey Laboratory Methods Manual, 2004), yaş yakma metodu ile organik madde (Hocaoğlu, 1970), $\mathrm{CaCO}_{3}$ ve KDK (Hızalan ve Ünal, 1966), 1N amonyum asetat ile Değişebilir Katyonlar ( U.S. Salinity Lab. Staff, 1954 ), Hacim ağırlığı(Blake ve Hartge, 1986), $\mathrm{LiBO}_{2} /$ nitrik asitte yakma yöntemiyle elde edilen ekstraklarda total element analizleri yapılmıştır. Majör ve minör elementler ICP AES'de, nadir toprak elementleri ise ICP MS'de okunmuştur. Majör elementler \% oksitler şeklinde, minör ve nadir toprak elementleri ise $\mathrm{mg} / \mathrm{kg}$ ve $\mu \mathrm{g} / \mathrm{kg}$ olarak belirlenmiştir. Ayrıca örneklerde yüksek sıcaklıkta (1000 ${ }^{\circ} \mathrm{C} 3$ saat) yanma kayıpları yüzde olarak belirlenmiştir (Chao ve Sanzolone, 1992).

\section{Bulgular ve Tartışma}

\subsection{Toprak profillerine ait morfolojik görünümler ve bazı fiziksel ve kimyasal özellikler}

Toprak profillerinin arazi tanımlamaları Çizelge 1 ve 2'de sunulmuştur. Çizelgelerden de görüldüğü gibi 1 nolu profil hariç profillerin tümü dik eğimli yamaç ve etek arazi fizyografyada, andezit- bazalt ana materyal üzerinde, xeric nem ve mesic sıcaklık rejiminde gelişmiştir. 2, 3 ve 4 numaralı profillerde A horizonundan başka tanımlayıcı 
horizon bulunmamaktadır. 1 numaralı profillerde ise A horizonuna ilaveten kambik B horizonu saptanmıştır. Horizon farklılaşmasının üst seviyede olmaması ve ana materyalin düşük ayrışma oranları, toprak gelişiminin başlangıç aşamalarında olduğunu göstermektedir. Profillerde renk $2.5 \mathrm{Y}$ ile $10 \mathrm{YR}$ arasında değişmekte olup kuru iken genelde yüksek value değerlerine sahiptir.

C horizonları ise daha yüksek value değerleri göstermiştir. Profillerin açıldığı bölgenin mera, meşe ve çam örtüsü altında olması yüzeyde organik maddenin alt katmanlara göre yüksek seviyelere çıkmasına neden olmuş ve yüzey horizonları ile yüzey altı horizonlarında anlamlı farklılıklar gözlenmiştir. Bu farklılıklar organik madde, kök ve biyolojik aktivite seviyelerindeki farklılıklardan kaynaklanmıştır. Alt horizonların tümünde $\mathrm{HCl}$ uygulamsı ile tepkime gözlemlenmemiştir.

Tanımlanan profillerde önemli bir farklılaşmanın bulunmayışı ana materyalin yavaş ayrıştığını, bu da bölgedeki toprakların toprak oluşumunun başlangıç aşamasında olduğunu göstermektedir. A horizonlarında granül, kambik B horizonunda ise köşeli blok strüktür görülmüştür. Çevredeki kireçtaşlarından oluşan karbonatlı materyalin su erozyonu ve atmosferik tozlarla kısmen taşıması nedeniyle yüzeyde $\mathrm{HCl}$ ile çok zayıf reaksiyon gözlenmemiştir. Ancak düşük yağış dış katılımla gelen $\mathrm{CaCO}_{3}$ 'ün alt horizonlara yıkanmasına yetmemiştir. Çalışılan profillere ait fiziksel ve kimyasal özellikler Çizelge 3'te belirtilmiştir.

Profillerde organik madde içeriği \% 0.01 ile \% 4.44 arasında değişmiştir. Toprak organik maddesi, bitki kökleri ve mikroorganizmaların organik kalıntıları parçalamaları sonucu oluşur ve mineral alterasyonunda son derece önemli bir faktördür.

Toprak organik maddesindeki düşük molekül ağırlıklı organik asitler, mineral yüzeyinde birçok kompleksler ve ligandlar oluşturarak ayrışmada ve dolayısıyla toprak genesisinde önemli bir role sahiptir. Çalışma alanındaki topraklarda organik madde yüzey horizonlarında ülkemiz kurak alanları için yüksek bir değere çıkmış olsa da genel olarak andisollerdaki oranlardan daha düşüktür.

Düşük yağış, uzun ve kurak yaz periyodu organik maddenin yüksek değerlere çıkmasına engel olmuştur. Ayrıca organik madde içeriği derinlikle ciddi miktarda azalmış ve yüzey horizonlarından sonra çok düşük değerlere inmiştir. Kireç genellikle yüzey horizonlarında yüzey altı horizonlarına göre daha yüksek bulunsa da genel olarak düşük kireç miktarı saptanmıştır.

Kireç içeriği \% 0.3 ile \% 1.8 arasında değişmiştir. Toprakların elektriksel iletkenlikleri $24-166 \mu$ mhos $\mathrm{cm}^{-1}$ arasında değişmiştir. Tüm profiller tuzsuzdur. Toprakların $\mathrm{pH}^{\prime}$ sı, ana materyalin tabiatı ve karbonatların içeriği ile ilişkili olarak genel olarak 7'nin altındadır. Nitekim pH değeri 3 ve 4 nolu profillerde tüm horizonlarda, 1 nolu profilde ise yüzey horizonlarında asidik, diğer horizonlarda ise alkalidir.

Çalışma alanındaki toprakların KDK'ları 0.49 ile 25.20 me $100 \mathrm{~g}^{-1}$ arasında değişmiş ve Kambik horizonlu profillerde düşük organik maddeye rağmen yüksek değerler çıkmıştır. KDK'nın bu kadar yüksek değerlere çıkması yüksek yük yoğunluklu tabakalı alumino silikatların (simektit) varlığını göstermektedir. Nitekim örneklerin kil fraksiyonlarının XRD'lerinde, $\mathrm{Mg}$ doygun örneklerde $14 \AA \mathrm{nm}$ yansımaları, gliserol uygulamalarında 16-17 $\AA$ 'a doğru genişlemiştir. Bu da simektit ve klorit -simektit ara tabakalı killerin bulunduğunu göstermektedir.

Topraklarda değişebilir katyonlar Ca 0.25-15.31 me $100 \mathrm{~g}^{-1}$, Mg 0.06-11.55 me $100 \mathrm{~g} \mathrm{~g}^{-1}$, Na 0.08-0.51 me $100 \mathrm{~g}^{-1}$ ve $\mathrm{K}$ 0.18-1.32 me $100 \mathrm{~g}^{-1}$ değişim aralığında ve tüm horizonlarda $\mathrm{Ca}>\mathrm{Mg}>\mathrm{K}>\mathrm{Na}$ olarak belirlenmiş̧ir. Değişebilir katyonların miktarı genelde derinlikle azalmıştır.

Buna bağlı olarak baz doygunluğu \% 69-100 arasında dağılım göstermiştir. Hacim ağırlı̆ğ değerleri 1.07-1.82 g $\mathrm{cm}^{-3}$ arasında değişim göstermiştir. Genelde hacim ağırlığı değerleri toprakların sahip olduğu yüksek kum içeriği nedeniyle yüksektir.

Toprakların hacim ağırlığı yüzeyde daha düşük olup yüzey altı horizonlarda yükselmiştir. Bu durum yüzeyde organik maddenin varlığından kaynaklanmıştır. Ayrıca hacim ağırlığı değerleri üzerine, $\mathrm{C}$ horizonlarının ayrışmış veya yumuşamış ana kaya formunda olması da etkili olmuştur. Bu nedenle hacim ağırlığı değerleri derinlikle artmıştır. Toprakların bünye dağılımları ise kil \% 1.1 - 35.1, kum \% 38.9 - 89.9, silt \% 5.0 - 32.0 arasında dağılım göstermektedir. Çalışılan toprak profilleri kendi içinde jeokimyasal olarak benzer özellikler göstermiştir. Topraklardaki majör ve minör elementlerin dağılımı Çizelge 4'te verilmiştir. 
Çizelge 1. Toprak Profillerinin Açıldığı Noktaların Arazi Özellikleri

Table 1. Land Features of the Soil Profiles

\begin{tabular}{|c|c|c|c|c|c|c|c|}
\hline \multirow[b]{2}{*}{ Pedon } & \multicolumn{2}{|c|}{ Koordinatlar } & \multirow{2}{*}{ Ana Materyal } & \multirow{2}{*}{ Yükseklik } & \multirow{2}{*}{ Arazi Pozisyonu } & \multirow{2}{*}{ Eğim (\%) } & \multirow{2}{*}{ Vejetasyor } \\
\hline & Kuzey & Doğu & & & & & \\
\hline I & $37^{\circ} 51^{\prime} 35^{\prime \prime}$ & $33^{\circ} 51^{\prime} 47^{\prime \prime}$ & Andezit-Bazalt & 1539 & Piedmont & 2 & Orman \\
\hline II & $37^{\circ} 51^{\prime} 35^{\prime \prime}$ & $33^{\circ} 51^{\prime} 47^{\prime \prime}$ & Andezit-Bazalt & 1894 & Dik Yamaç & 30 & Mera \\
\hline III & $37^{\circ} 51^{\prime} 35^{\prime \prime}$ & $33^{\circ} 51^{\prime} 47^{\prime \prime}$ & Andezit-Bazalt & 1537 & Dik Yamaç & 15 & Orman \\
\hline IV & $37^{\circ} 51^{\prime} 35^{\prime \prime}$ & $33^{\circ} 51^{\prime} 47^{\prime \prime}$ & Andezit-Bazalt & 1563 & Dik Yamaç & 20 & Orman \\
\hline
\end{tabular}

Cizelge 2. Toprak Profillerine Ait Morfolojik Görünümler

Table 2. Morphological Specifications of Soil Profiles

\begin{tabular}{|c|c|c|c|c|c|c|c|c|}
\hline \multirow[t]{2}{*}{ Pedon } & \multirow[t]{2}{*}{ Horizon } & \multirow[t]{2}{*}{ Derinlik (cm) } & \multicolumn{2}{|c|}{ Renk } & \multirow[t]{2}{*}{ *Strüktür } & \multirow[t]{2}{*}{ *Kıvam } & \multirow[t]{2}{*}{ Arazi Tekstürü } & \multirow[t]{2}{*}{ Biyolojik Aktivite } \\
\hline & & & Kuru & Nemli & & & & \\
\hline \multirow{6}{*}{ I } & A1 & $0-28$ & 10YR4/4 & 10YR4/3 & $\mathrm{Gr}$ & ÇSr-Sk-P & Kumlu Kil & Çok \\
\hline & A2 & $28-76$ & 10YR4/3 & 10YR2/3 & $\mathrm{Gr}$ & ÇSr-Sk-ÇP & Kumlu Kil & Çok \\
\hline & Bw1 & 76-164 & 10YR4/3 & 10YR2/3 & KB & ÇSr-ÇSk-ÇP & Kil & Orta \\
\hline & Bw2 & 164-189 & 10YR4/3 & 10YR2/3 & KB & ÇSr-ÇSk-ÇP & Kil & $\mathrm{Az}$ \\
\hline & BC & 189-209 & 10YR5/4 & 10YR3/4 & $\mathrm{KB}$ & ÇSr-Sk-ÇP & Kil & $\mathrm{Az}$ \\
\hline & C & +209 & 10YR5/4 & 10YR4/4 & Ма & ÇSr-Sk-ÇP & Kil & $\mathrm{Az}$ \\
\hline \multirow{3}{*}{ II } & A1 & $0-34$ & 10YR5/3 & 10YR4/4 & $\mathrm{Gr}$ & Y-G-PD & Siltli Tın & Orta \\
\hline & A2 & $34-55$ & 10YR5/3 & 7,5YR4/3 & Gr & HF-G-PD & Siltli Tın & Orta \\
\hline & $\mathrm{R}$ & +55 & - & - & - & - & - & - \\
\hline & A1 & $0-27$ & 10YR6/2 & 7,5YR3/3 & Gr & Y-Sk-PD & Killi Kumlu Tın & Çok \\
\hline \multirow{5}{*}{ III } & A2 & $27-61$ & 10YR5/4 & 10YR4/4 & Gr & HF-G-PD & Killi Kumlu Tın & Çok \\
\hline & A3 & 61-101 & 2,5Y7/2 & 10YR4/3 & $\mathrm{Gr}$ & HF-D-PD & Kumlu Tin & Orta \\
\hline & C1 & 101-149 & 2,5Y7/2 & 10YR5/1 & Ма & HF-G-PD & Kumlu Tin & $\mathrm{Az}$ \\
\hline & $\mathrm{C} 2 \mathrm{r}$ & $149-174$ & 2,5Y7/1 & 10YR4/2 & Ма & Sr-D-PD & Kumlu Tin & $\mathrm{Az}$ \\
\hline & $\mathrm{R}$ & +174 & - & - & - & - & - & - \\
\hline \multirow{5}{*}{ IV } & A1 & $0-11$ & 10YR6/4 & 10YR4/3 & Gr & HF-G-PD & Killi Kumlu Tın & Çok \\
\hline & A2 & $11-65$ & 10YR7/3 & 10YR4/3 & Gr & Sr-G-PD & Siltli Kum & Çok \\
\hline & A3 & 65-101 & 10YR7/3 & 10YR4/4 & Gr & HF-G-PD & Kum & $\mathrm{Az}$ \\
\hline & C1 & 101-144 & 10YR7/2 & 10YR4/3 & Ма & HF-G-PD & Kumlu Ayrş. Matryl. & $\mathrm{Az}$ \\
\hline & $\mathrm{C} 2 \mathrm{r}$ & +144 & 10YR7/1 & 10YR5/1 & Мa & HF-ÇG-PD & Kumlu Ayrş. Matryl. & $\mathrm{Az}$ \\
\hline
\end{tabular}

*Gr: Granüler, Pri: Prizmatik, KB: Köşeli Blok, Ma: Masif, Y: Yumuşak, HF. Hafif Sert, Sr:Sert, ÇSr: Çok Sert, Sk: Sıkı, ÇSk: Çok Sıkı, G: Gevşek, ÇG: Çok gevşek, P: Plastik, ÇP: Çok Plastik 
Çizelge 3. Profillere Ait Bazı Fiziksel ve Kimyasal Özellikler

Table 3. Some Physical and Chemical Properties of Profiles

\begin{tabular}{|c|c|c|c|c|c|c|c|c|c|c|c|c|c|c|c|}
\hline \multirow[t]{2}{*}{ Pedon } & \multirow[t]{2}{*}{ Horizon } & \multirow[t]{2}{*}{$\begin{array}{l}\text { Derinlik } \\
\text { (cm) }\end{array}$} & \multirow{2}{*}{$\begin{array}{c}\mathrm{pH}_{\text {(Saf }} \\
\text { Su) } \\
(1 / 2.5)\end{array}$} & \multirow[t]{2}{*}{$\begin{array}{c}\text { EC } \\
(\mu \mathrm{S} / \mathrm{cm})\end{array}$} & \multirow{2}{*}{$\begin{array}{l}\text { Organik } \\
\text { Madde } \\
\text { (\%) }\end{array}$} & \multirow{2}{*}{$\begin{array}{c}\text { Hacim } \\
\text { A ğırlığ } 1 \\
\left(g^{\prime} . \text { cm }^{-}\right. \\
3 \text { ) }\end{array}$} & \multirow{2}{*}{$\begin{array}{c}\mathrm{KDK} \\
\left(\mathrm{mq} .100 \mathrm{gr}^{-}\right. \\
\left.{ }^{1}\right)\end{array}$} & \multirow{2}{*}{$\begin{array}{c}\text { Baz } \\
\text { Doygunluğu } \\
(\%)\end{array}$} & \multicolumn{4}{|c|}{$\begin{array}{l}\text { Değişebilir Katyonlar } \\
\left(\mathrm{mq} .100 \mathrm{~g}^{-1}\right)\end{array}$} & \multicolumn{3}{|c|}{$\begin{array}{c}\text { Tane Büyüklük } \\
\text { Dağılımı } \\
(\%)\end{array}$} \\
\hline & & & & & & & & & $\mathrm{Ca}$ & $\mathrm{Mg}$ & $\mathrm{Na}$ & $\mathrm{K}$ & Kum & Kil & Silt \\
\hline \multirow{6}{*}{ I } & A1 & $0-28$ & 6.56 & 166 & 2.99 & 1.52 & 15.80 & 100 & 11.60 & 5.14 & 0.29 & 1.12 & 41.9 & 26.1 & 32.0 \\
\hline & A2 & $28-76$ & 6.79 & 60 & 1.41 & 1.48 & 18.79 & 100 & 11.91 & 6.13 & 0.16 & 1.32 & 38.9 & 34.1 & 27.0 \\
\hline & Bw1 & $76-164$ & 6.94 & 59 & 2.04 & 1.36 & 25.20 & 100 & 15.31 & 10.96 & 0.34 & 0.70 & 39.9 & 35.1 & 25.0 \\
\hline & Bw2 & 164-189 & 7.01 & 39 & 1.08 & 1.66 & 21.92 & 100 & 12.83 & 9.26 & 0.35 & 0.67 & 46.9 & 29.1 & 24.0 \\
\hline & $\mathrm{BC}$ & 189-209 & 7.06 & 72 & 0.70 & 1.41 & 22.27 & 100 & 12.55 & 11.55 & 0.39 & 0.69 & 49.9 & 25.1 & 25.0 \\
\hline & C & +209 & 7.43 & 91 & 0.60 & 1.4 & 21.61 & 74 & 13.92 & 0.91 & 0.51 & 0.64 & 51.9 & 21.6 & 26.5 \\
\hline \multirow{3}{*}{ II } & A1 & $0-34$ & 7.22 & 69 & 3.23 & 1.41 & 11.17 & 78 & 7.49 & 0.34 & 0.17 & 0.68 & 53.9 & 20.1 & 26.0 \\
\hline & A2 & $34-55$ & 7.02 & 58 & 1.69 & 1.36 & 9.13 & 82 & 6.22 & 0.35 & 0.19 & 0.73 & 54.9 & 19.1 & 26.0 \\
\hline & $\mathrm{R}$ & +55 & - & - & - & 1.32 & - & - & - & - & & - & - & & - \\
\hline \multirow{5}{*}{ III } & A1 & $0-27$ & 6.61 & 72 & 4.11 & 1.42 & 10.21 & 80 & 7.20 & 0.29 & 0.10 & 0.62 & 61.9 & 16.1 & 22.0 \\
\hline & A2 & $27-61$ & 6.60 & 50 & 1.30 & 1.59 & 5.73 & 85 & 4.12 & 0.16 & 0.13 & 0.45 & 71.9 & 12.1 & 16.0 \\
\hline & A3 & 61-101 & 6.93 & 39 & 0.29 & 1.45 & 2.95 & 81 & 1.79 & 0.08 & 0.21 & 0.31 & 82.9 & 8.1 & 9.0 \\
\hline & C1 & $101-149$ & 6.67 & 51 & 0.07 & 1.51 & 0.49 & 100 & 0.25 & 0.01 & 0.12 & 0.23 & 89.9 & 5.1 & 5.0 \\
\hline & $\mathrm{C} 2 \mathrm{r}$ & 149-174 & 6.92 & 55 & 0.10 & - & 0.94 & 95 & 0.54 & 0.07 & 0.08 & 0.20 & 88.9 & 5.1 & 6.0 \\
\hline \multirow{6}{*}{ IV } & $\mathrm{R}$ & +174 & - & - & - & 1.57 & - & - & - & - & & - & - & & - \\
\hline & A1 & $0-11$ & 6.78 & 69 & 1.57 & 1.56 & 7.54 & 80 & 5.16 & 0.24 & 0.13 & 0.52 & 58.9 & 17.1 & 24.0 \\
\hline & A2 & $11-65$ & 6.43 & 56 & 0.60 & 1.54 & 5.40 & 78 & 3.39 & 0.26 & 0.16 & 0.43 & 66.9 & 17.1 & 16.0 \\
\hline & A3 & 65-101 & 6.67 & 29 & 0.17 & 1.56 & 3.47 & 69 & 1.70 & 0.21 & 0.15 & 0.35 & 76.9 & 7.6 & 15.5 \\
\hline & C1 & $101-144$ & 6.55 & 24 & 0.04 & 1.35 & 0.93 & 88 & 0.48 & 0.07 & 0.09 & 0.18 & 82.9 & 5.1 & 12.0 \\
\hline & $\mathrm{C} 2 \mathrm{r}$ & +144 & 6.56 & 34 & 0.01 & 1.39 & 0.71 & 100 & 0.49 & 0.06 & 0.08 & 0.18 & 83.9 & 1.1 & 15.0 \\
\hline
\end{tabular}


Çizelge 4. Profillerdeki Bazı Majör Elementlerinin Dağılımı ve Ayrışma Oranları

Table 4. Distribution and Weathering Rates of Some Major Elements in Profiles

\begin{tabular}{|c|c|c|c|c|c|c|c|c|c|c|c|c|c|c|c|c|c|c|}
\hline 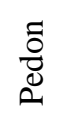 & 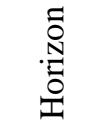 & $\mathrm{SiO}_{2}$ & $\mathrm{Al}_{2} \mathrm{O}_{3}$ & $\mathrm{Fe}_{2} \mathrm{O}_{3}$ & MgO & $\mathrm{CaO}$ & $\mathrm{Na}_{2} \mathrm{O}$ & $\mathrm{K}_{2} \mathrm{O}$ & $\mathrm{TiO}_{2}$ & $\mathrm{P}_{2} \mathrm{O}_{5}$ & $\mathrm{MnO}$ & LOI & Toplam & CIA & CIW & PIA & $\mathrm{P}$ & $\mathrm{Baz} / \mathrm{R}_{2} \mathrm{O}_{3}$ \\
\hline \multirow{5}{*}{ I } & A1 & 57.35 & 17.21 & 5.85 & 2.09 & 4.24 & 2.62 & 1.66 & 0.87 & 0.13 & 0.14 & 7.6 & 99.80 & 55.99 & 59.48 & 50.13 & 81.56 & 0.86 \\
\hline & A2 & 56.76 & 18.15 & 6.44 & 2.19 & 3.88 & 2.38 & 1.71 & 0.91 & 0.14 & 0.14 & 7.1 & 99.81 & 59.21 & 63.03 & 53.16 & 80.47 & 0.77 \\
\hline & Bw1 & 56.37 & 17.93 & 6.41 & 2.26 & 3.83 & 2.16 & 1.55 & 0.87 & 0.14 & 0.14 & 8.1 & 99.79 & 60.16 & 63.75 & 54.51 & 80.56 & 0.76 \\
\hline & Bw2 & 56.71 & 18.26 & 6.42 & 2.42 & 3.93 & 2.40 & 1.70 & 0.85 & 0.12 & 0.12 & 6.8 & 99.81 & 59.04 & 62.79 & 53.08 & 80.44 & 0.80 \\
\hline & $\mathrm{C}$ & 55.98 & 18.50 & 6.66 & 2.64 & 4.10 & 2.37 & 1.63 & 0.85 & 0.15 & 0.11 & 6.8 & 99.80 & 59.15 & 62.69 & 53.49 & 79.97 & 0.82 \\
\hline \multirow{3}{*}{ II } & A1 & 57.88 & 17.63 & 5.09 & 2.20 & 4.62 & 3.11 & 1.64 & 0.69 & 0.14 & 0.10 & 6.7 & 99.82 & 54.07 & 57.19 & 48.61 & 81.89 & 0.95 \\
\hline & A2 & 57.88 & 18.16 & 5.47 & 2.37 & 4.66 & 3.14 & 1.54 & 0.74 & 0.11 & 0.10 & 5.6 & 99.83 & 54.67 & 57.56 & 49.64 & 81.33 & 0.93 \\
\hline & $\mathrm{R}$ & 63.53 & 16.29 & 4.27 & 2.33 & 5.20 & 3.59 & 2.08 & 0.56 & 0.16 & 0.08 & 1.7 & 99.84 & 48.57 & 52.07 & 41.84 & 84.56 & 1.18 \\
\hline \multirow{5}{*}{ III } & A1 & 58.33 & 16.77 & 5.02 & 2.33 & 4.65 & 3.24 & 1.77 & 0.68 & 0.15 & 0.10 & 6.8 & 99.82 & 52.19 & 55.51 & 46.22 & 82.64 & 1.02 \\
\hline & A2 & 60.24 & 17.24 & 5.13 & 2.41 & 4.72 & 3.47 & 1.79 & 0.67 & 0.12 & 0.09 & 3.9 & 99.83 & 51.92 & 55.15 & 46.07 & 82.74 & 1.03 \\
\hline & A3 & 61.68 & 16.90 & 5.09 & 2.57 & 4.85 & 3.57 & 1.89 & 0.65 & 0.13 & 0.09 & 2.4 & 99.83 & 50.67 & 53.99 & 44.52 & 83.33 & 1.10 \\
\hline & C1 & 62.73 & 16.50 & 5.01 & 2.61 & 5.11 & 3.69 & 2.06 & 0.68 & 0.16 & 0.09 & 1.2 & 99.83 & 48.92 & 52.39 & 42.29 & 83.84 & 1.16 \\
\hline & $\mathrm{R}$ & 63.42 & 16.23 & 4.05 & 2.18 & 5.08 & 3.78 & 2.19 & 0.54 & 0.16 & 0.07 & 2.1 & 99.85 & 48.16 & 51.82 & 41.11 & 84.68 & 1.18 \\
\hline \multirow{5}{*}{ IV } & A1 & 58.18 & 17.90 & 5.67 & 2.40 & 4.96 & 3.29 & 1.54 & 0.79 & 0.10 & 0.10 & 4.9 & 99.82 & 53.00 & 55.75 & 48.05 & 81.45 & 0.98 \\
\hline & A2 & 59.59 & 18.08 & 5.42 & 2.27 & 4.95 & 3.44 & 1.58 & 0.74 & 0.08 & 0.09 & 3.6 & 99.84 & 52.75 & 55.52 & 47.75 & 81.84 & 0.98 \\
\hline & A3 & 63.23 & 16.39 & 4.34 & 2.05 & 4.70 & 3.40 & 1.94 & 0.56 & 0.11 & 0.07 & 3.0 & 99.85 & 50.62 & 54.14 & 44.11 & 84.40 & 1.07 \\
\hline & C1 & 63.53 & 16.39 & 4.29 & 2.31 & 5.05 & 3.73 & 2.09 & 0.57 & 0.14 & 0.08 & 1.7 & 99.84 & 48.70 & 52.21 & 41.96 & 84.47 & 1.17 \\
\hline & C2r & 62.81 & 16.44 & 4.61 & 2.42 & 5.07 & 3.72 & 2.11 & 0.60 & 0.15 & 0.08 & 1.8 & 99.83 & 48.75 & 52.30 & 41.96 & 84.13 & 1.16 \\
\hline
\end{tabular}


Profillerde $\mathrm{SiO}_{2}$ içeriği içeriği \%55,98- 63.53 arasında dağılım göstermiştir. $\mathrm{Al}_{2} \mathrm{O}_{3}$ içeriği \%16.18- 18.50 arasında değişmiştir. Toprakta bulunan $\mathrm{Al}$ doğrudan kil dağılımı ile ilgilidir ve olgun topraklarda $\mathrm{Al}_{2} \mathrm{O}_{3}$ miktarı artmaktadır. Araştırılan topraklarda $\mathrm{Al}_{2} \mathrm{O}_{3}$ miktarı düşük ayrışma oranı nedeniyle solumda ana materyale yakın değerler göstermiştir. Aynı zamanda Si ve Al değerleri profillerde kum ve kil içeriğine bağlı olarak farklılaşmıştır. $\mathrm{Fe}_{2} \mathrm{O}_{3}$ miktarı \%4.05-6.66 arasında değişmekle birlikte en yüksek değer yüzey horizonlarında görülmüştür. $\mathrm{CaO}$ tüm göstermiştir. $\mathrm{CaO} \% 3.83-5.20$ arasında dağılım göstermiş ve ana materyallerde üst horizonlara göre daha yüksek değerler belirlenmiştir. $\mathrm{MgO}$ değerleri ise \%2.05 ile 2.64 arasında değişim göstermiş. $\mathrm{MgO}$ değerlerinin genelde yüksek olması ferromagnezyen minerallerin bulunmasından kaynaklanmıştır. Nitekim birincil mineral çözümlemelerin de yüksek amfibol ve biyotit piklerine rastlanmıştır. $\mathrm{K}_{2} \mathrm{O}$ ve $\mathrm{Na}_{2} \mathrm{O}$ değerleri sırasıyla \%1.54-2.11, \%2.16-3.78 arasında değişim göstermiştir. Bu durum andezitte ve bazaltta bol miktarda bulunan feldispatların ve aynı zamanda mikalar ve hornblentlerin de dağılımıyla yakından ilişkilidir. $\mathrm{TiO}_{2}$ ayrışma ortamlarında dayanıklı bir bileşen olup kimyasal değişimin belirlenmesinde kullanılan bir elementtir. Topraklarda $\mathrm{MnO} \% 0.07-0.14, \mathrm{P}_{2} \mathrm{O}_{5}$ ise \% 0.08-0.16 arasında dağılım göstermiştir. Diğer minör elementlerin dağılımında ise horizonlar arasında düzenli bir değişim trendi gözlenmemiştir. Araştırmada değerlendirilen kriterler göz önüne alındığında toprak oluşumunda ayrışmanın yavaş seyrettiğgi, toprağa katılmaların, kayıpların ve ayrılmaların ve değişimlerin çok az olduğu görülmektedir. Araştırma topraklarında toplam $\mathrm{Fe}_{2} \mathrm{O}_{3}$ miktarlarına karşılık serbest demir oksit oranları çok düşüktür ve bu da ayrışmanın düşük olduğunu göstermektedir. Bu durumun hornblendin zayıf ayrışmasından kaynaklandığı bilinmektedir. Geriye kalan demirin killerin kristal yapılarında bulunma olasılığı yüksektir. Profillerde ana materyaldeki sodyum oranlarına göre yüzey horizonlarındaki $\mathrm{Na}$ miktarları arasında önemli bir farklılaşma görülmemiştir. $\mathrm{Bu}$ eğilim diğer alkali katyonlar için de geçerlidir. Tam tersi $\mathrm{Ca}, \mathrm{K}, \mathrm{Mg}$ gibi katyonlar yüzey horizonlarında bitkisel döngü kaynaklı artı̧̧ göstermiştir. Bu da ayrışmanın çok az olduğunu, buna bağlı olarak alkali katyonların yıkanmadığını göstermektedir. Profillerde toplam $\mathrm{TiO}_{2} \% 0.54-0.91$ arasında dağıllım göstermiştir. Bu elementin çalışılan tüm profillerde solumdaki dağılımları birbirine çok yakın ve miktar olarak çok düşük bulunmuştur. İmmobil bir element olan $\mathrm{TiO}_{2}{ }^{\prime}$ in $\%$ miktarları toprağın ayrışma düzeyini ortaya koymaktadır. Toprak gelişiminin artmasıyla diğer elementlerin yıkanmasına bağlı olarak oransal miktarı artan bu element araştırma bölgesi topraklarında pedojenik gelişimin zayıflığına paralel olarak düşük değerler göstermektedir.

\subsection{Ayrışma indeksleri}

Topraklarda ayrışmanın tanımlanması için çok sayıda indeks ortaya konulmuştur (Harnois, 1988; Nesbit ve Young, 1989). Tüm indekslerin genel prensibi benzerdir ve bazik katyonlar (Ca, Mg, K, Na) ile Al ve Si gibi katyonlar arasındaki değişik oranların belirlenmesine dayanır. Bu çalışmada profillerin ayrışma oranlarının sayısallaştırılması için aşağıda verilen indeksler kullanılmıştır.

a- Kimyasal alterasyon indeksi (CIA) (Nesbitt ve Young, 1982)

$\mathrm{CIA}=(100)\left[\mathrm{Al}_{2} \mathrm{O}_{3} /\left(\mathrm{Al}_{2} \mathrm{O}_{3}+\mathrm{CaO}^{*}+\mathrm{Na}_{2} \mathrm{O}+\mathrm{K}_{2} \mathrm{O}\right)\right]$

b- Kimyasal ayrışma indeksi (CIW) (Harnois, 1988)

$\mathrm{CIW}=(100)\left[\mathrm{Al}_{2} \mathrm{O}_{3} /\left(\mathrm{Al}_{2} \mathrm{O}_{3}+\mathrm{CaO}+\mathrm{Na}_{2} \mathrm{O}\right)\right]$

c- Bazlar $/ \mathrm{R}_{2} \mathrm{O}_{3}$ oran1 (Birkeland, 1999),

Bazlar $/ \mathrm{R}_{2} \mathrm{O}_{3}=\left(\mathrm{MgO}+\mathrm{CaO}+\mathrm{Na}_{2} \mathrm{O}+\mathrm{K}_{2} \mathrm{O}\right) /\left(\mathrm{TiO}_{2}+\mathrm{Fe}_{2} \mathrm{O}_{3}+\mathrm{Al}_{2} \mathrm{O}_{3}\right)$

d-Plajiyoklas alterasyon indeksi (PIA) (Fedo ve ark., 1995)

$\mathrm{PIA}=(100)\left[\left(\mathrm{Al}_{2} \mathrm{O}_{3}-\mathrm{K}_{2} \mathrm{O}\right) /\left(\mathrm{Al}_{2} \mathrm{O}_{3}+\mathrm{CaO}+\mathrm{Na}_{2} \mathrm{O}+\mathrm{K}_{2} \mathrm{O}\right)\right]$

e- Product Indeks (P) (Reiche, 1950)

$\mathrm{P}=(100)\left[\mathrm{SiO}_{2} /\left(\mathrm{TiO}_{2}+\mathrm{Fe}_{2} \mathrm{O}_{3}+\mathrm{Al}_{2} \mathrm{O}_{3}+\mathrm{SiO}_{2}\right)\right]$

Eşitliklerdeki $\mathrm{CaO}^{*}$ değeri silikat minerallerinden kaynaklanan $\mathrm{CaO}$ değeridir. Bu nedenle karbonat ve apatit düzeltmesi yapılarak kullanılır. Zira silikat minerallerindeki en önemli $\mathrm{CaO}$ kaynaklarından biri de apatittir. Apatit düzeltmesi yapılan $\mathrm{CaO}$ değeri $\mathrm{Na}_{2} \mathrm{O}$ değerinden daha düşük çıkarsa indekslerde bu değer kullanılır. Daha yüksek çıkması durumunda ise $\mathrm{CaO}$ değeri olarak $\mathrm{Na}_{2} \mathrm{O}$ değeri kullanılır (Mclennan ve ark., 1993). Bu çalışmada da hem kireç hem de ölçülen $\mathrm{P}_{2} \mathrm{O}_{5}$ değeri kullanılarak apatit düzeltmesi yapılmıştır. Çalışma alanındaki toprakların jeokimyasal özelliklerinden üretilen bazı ayrışma oranları Çizelge 5'de verilmiştir. Profillerde CIA değerleri \%48.16 - 60.16 arasında değişmiş ve horizonlar arasında önemli farklılıklar gözlenmiştir. En düşük CIA değeri $\mathrm{R}$ ve $\mathrm{C}$ katmanlarında bulunmuş ve genel olarak derinlikle azalma trendi gözlenmemiştir. Profiller arasında CIW değerleri 1 numaralı profil hariç önemli değişim göstermemiştir. CIW değerleri 52.07 ile 63.75 arasında derinlikle azalma trendi göstermiştir. Kambik horizon bulunan 1 nolu profilde bu değişim kambik horizonlarda artış, sonra tekrar 
azalma şeklinde olmuştur. Baz/ $\mathrm{R}_{2} \mathrm{O}_{3}$ değeri 1'e yakın veya 1'in üzerinde olup 0.76 ile 1.19 arasında değişmiştir. Değerlerin horizonlar arasındaki dağılımında da derinlikle değişim gözlenmiştir. PIA değerleri profillerde birbirine yakın bir değişim göstermiş ve \%41.11-76.98 arasında, P değerleri ise \%79.17-84.68 arasında değişmiştir. PIA genel olarak derinlikle azalma $\mathrm{P}$ ise derinlikle artma eğilimi göstermiştir. CIA değeri kimyasal ayrışma ile $\mathrm{Ca}$, $\mathrm{Na}$ ve $\mathrm{K}$ gibi bazik katyonların minerallerden uzaklaşması işlemine dayanır ve toprak içerisinde birincil ve ikincil minerallerin oranını yansıtan bir değerdir. Ayrışma parçalanma ile birlikte bu değer artar. CIA hidrolitik ayrışma ile feldspatların killere alterasyonun derecesini yansıtır ve nispi olarak kil miktarına işaret eder. Yoğun olarak ayrışmış ve bol miktarda kaolinit gibi residiyal killer veya gibsit gibi mineralleri içeren toprak veya sedimentlerde CIA değeri 100'dür. Ayrışmamış üst kaya kabuğu için ise bu değer 50 dir (Fedo ve ark., 1995). Şeyller için bu değer ortalama \% 70 - 75 arasında değişir. CIA değerleri çok az ayrışmış (50-60), az ayrışmış (60-70) orta derecede ayrışmış (70-80), ileri derecede ayrışmış (80-90) ve aşırı derecede ayrışmış (90-100) olarak sınıflandırıldığında (Nesbitt and Young, 1982) çalışma alanındaki profillerin çok az ayrışmış olduğu görülmektedir. Genellikle CIA değerlerinin derinlikle azalması ayrışma parçalanmanın derinlikle birlikte azaldığını gösterir. Ülkemizin en genç volkanik malzemelerinden birine sahip olan Hasandağın'da CIA değerleri yaş ile uyum içinde düşük çıkmıştır. CIW değeri hiç ayrışmamış kayada 50 yoğun olarak ayrışmış ortamlarda ise 100 değerine ulaşır ve ayrışma ile artar. CIW değeri 51.82- 63.75 arsında dağılım göstermiştir. CIA için kullanılan sınıflandırma CIW için de yapılırsa, CIW profillerin düşük ayrışmaya uğradığ 1 görülmektedir. Bu da söz konusu toprakların zamana bağlı olarak düşük yoğunlukta ayrışma süreçlerine maruz kaldığını gösteren bir diğer kanıt olarak ortaya çıkmaktadır. Bazlar/ $\mathrm{R}_{2} \mathrm{O}_{3}$ oranı profil 2, 3 ve 4'de en az ayrışmayı gösterir şekilde en yüksek değerler bulunmuştur. Çalışılan tüm profillerde bu indeks formasyon yaşları ve otokton topraklarda derinlikle ayrışmanın azalması kuralı ile uyum içindedir. PIA ayrışma derecesinin sayısallaştırılmasında CIA'ya alternatif olarak kullanılan diğer bir indekstir ve plajyoklasların alterasyonu hakkında bilgi verir. Bu değer 41.11 ile 54.51 arasında değişim göstermiştir. Çalışılan tüm profillerde PIA değeri jeolojik yaşla uyum içinde dağılım göstermiş̧ir çok düşük değerler göstermiştir. Bu durum toprakların kil mineralojisi ile de uyum içindedir. Düşük PIA değerleri, Hasandağ'ındaki düşük kil içeriği feldspatlardaki alterasyonun ve kaolinleşmenin düşüklügünü destekleyen başka bir delil durumundadır. Benzer bir eğilimde de Product indeksi (P) değerleri dağılımında görülmüsşür. P değeri 79.97- 84.68 arasında dağılım göstermiştir. Profiller arasında anlamlı bir değişim gözlenmemiştir.

\subsection{Kütle dengesi modeli}

Kütle dengesi modeli toprak oluşumu süresi boyunca herhangi bir element için kayıp - kazanç ve dönüşümler sonucu ortaya çıkan miktarlarının sayısallaştıılmasında kullanılan bir metottur (Brimhall ve Dietrich, 1987). Toprakların kütle dengesi analizlerinin yapılabilmesi için horizon ve ana materyal veya ana kayanın hacim ağırlığı, hacim, kimyasal kompozisyonlarının bilinmesi ve karşılaştırılması gereklidir (Brimhall ve ark., 1991b). Bu özelliklere bağlı olarak kütle dengesi eşitliği toprak ayrışması ve ana materyalle ilişkili olarak açık sistem kayıp ve kazançlarını ortaya koymak için geliştirilmiştir. Toprak oluşumu süresince hacimsel ve kütlesel değişim eşitliği Brimhall ve ark., (1988, 1991a, b), Chadwick ve ark., (1990), tarafindan ortaya konmuştur. Bu tür eşitliklerde zenginleşme ve yıkanma faktörü Ti veya $\mathrm{Zr}$ gibi immobil bir element kullanılarak belirlenir. Bu metot silikatlarca zengin kayaçla çalışma yapan birçok araştırıı tarafından uygulanmıştır (Langley-Turnbaugh; Nieuwenhuyse ve Van Breemen, 1997; White, 1995). Bu prosedür Egli ve Fitze (2000) tarafından tekrar gözden geçirilmiştir.

Kütle dengesi hesabında standardize edilmiş hacimsel değişim $(\boldsymbol{\varepsilon})$ katsayısı toprakların seyrelme veya zenginleşmesinin hesaplanmasında kullanılır. Kütle dengesi modeli aşağıda sunulmuştur.

$$
M_{j f l u x(s w)}=\sum_{\alpha=1}^{\wedge} C_{j p} P_{p}\left(\frac{1}{\varepsilon+1}\right) T_{j W} \Delta z
$$

Mjflux, negatif ise sistemden kayıp, pozitif ise sisteme katılım olduğunu gösterir. Eğer toprak oluşumunun başlangıcı biliniyorsa bulunan değeri geçen yıla bölünerek yıllık ayrışma oranı belirlenir. Çalışmada $\mathrm{Zr}$ hacimsel değişimi hesaplamada immobil element olarak seçilmiştir. $\mathrm{Zr}$ ve Ti toprak ortamında genellikle düşük hereket kabiliyetine sahip oldukları için immobil element olarak kullanılır. (Marshall Ve Haseman, 1942; Brimhall ve Dietrich, 1987; Harden, 1988; Chadwick ve ark., 1990; Brimhall ve ark., 1991a,b; Merritts ve ark., 1992). Çizelge 5 'ten de görüldüğü gibi kütle taşınım fonksiyonu anlamlı sonuçlar vermiştir. Hasandağında P1 dışında kütle fonksiyonu tüm katyonlar için negatif çıkmıştır. Bu durum profillerden net kaybı ortaya koymaktadır. 2, 3 ve 4. profillerde miktar olarak en büyük kayıp silikada, oran olarak ise en büyük kayıp Na'da gözlenmiştir. Profil 1'de görülen anomali ve buna bağlı olarak ortaya çıkan pozitif kütle taşınım fonksiyonu ise, muhtemelen söz konusu profilin açıldığı alanın bir piedmont olması ve çevredeki yüksek arazilerden gelen silika ve diğer katyonlarca zengin suların neden olduğu zenginleşme nedeniyle oluşmuştur. Diğer profillerde ise desilikazasyon en baskın süreç 
Çizelge 5. Profillerde bazı elementler için horizonların kütle taşınım fonksiyon değerleri $(\tau)$ ve kütle kayıp kazançları (gr $\mathrm{cm}-2)$

Table 5.

\begin{tabular}{|c|c|c|c|c|c|c|c|c|c|c|c|c|c|c|c|}
\hline \multirow{2}{*}{ Pedon } & \multirow{2}{*}{ Horizon } & \multicolumn{2}{|c|}{$\mathrm{Si}$} & \multicolumn{2}{|c|}{$\overline{\mathrm{Al}}$} & \multicolumn{2}{|c|}{$\mathrm{Ca}$} & \multicolumn{2}{|c|}{$\mathrm{Mg}$} & \multicolumn{2}{|c|}{$\mathrm{Na}$} & \multicolumn{2}{|c|}{$\bar{K}$} & \multicolumn{2}{|c|}{$\mathrm{Fe}$} \\
\hline & & $(\tau)$ & $\mathrm{M}_{\text {jflux }}$ & $(\tau)$ & $\mathbf{M}_{\text {jlux }}$ & $(\tau)$ & $\mathrm{M}_{\text {jllux }}$ & $(\tau)$ & $\mathrm{M}_{\text {jflux }}$ & $(\tau)$ & $\mathrm{M}_{\text {jflux }}$ & $(\tau)$ & $\mathbf{M}_{\text {jflux }}$ & $(\tau)$ & $\mathbf{M}_{\text {jflux }}$ \\
\hline \multirow{7}{*}{ I } & A1 & 0.166 & 35.45 & 0.059 & 5.39 & 0.177 & 3.59 & -0.099 & -1.29 & 0.258 & 3.02 & 0.159 & 1.28 & 0.000 & 0.00 \\
\hline & A2 & 0.079 & 304.33 & 0.044 & 6.32 & 0.007 & 0.22 & -0.117 & -2.40 & 0.069 & 1.27 & 0.117 & 1.48 & 0.029 & 1.50 \\
\hline & Bw1 & 0.108 & 83.68 & 0.066 & 20.45 & 0.028 & 1.92 & -0.058 & -2.57 & 0.003 & 0.12 & 0.046 & 1.26 & 0.059 & 6.58 \\
\hline & Bw2 & 0.114 & 23.35 & 0.086 & 715.95 & 0.054 & 1.05 & 0.008 & 9.50 & 0.114 & 121.58 & 0.147 & 107.82 & 0.060 & 179.82 \\
\hline & $\mathrm{BC}$ & 0.039 & 6.90 & 0.021 & 1.31 & -0.019 & -0.26 & 0.000 & 0.00 & 0.009 & 0.07 & 0.082 & 0.45 & 0.017 & 4.76 \\
\hline & $\mathrm{C}$ & 0 & 0 & 0 & 0 & 0 & 0 & 0 & 0 & 0 & 0 & 0 & 0 & 0 & 0 \\
\hline & Toplam & & 758.03 & & 749.43 & & 6.52 & & 3.25 & & 126.06 & & 112.29 & & 192.66 \\
\hline \multirow{4}{*}{ II } & A1 & -0.165 & -41.60 & -0.008 & -0.77 & -0.211 & -3.66 & -0.134 & -0.26 & -0.206 & -2.04 & -0.277 & -1.92 & 0.093 & 1.32 \\
\hline & $\mathrm{A} 2$ & -0.198 & -40.22 & -0.019 & -0.43 & -0.186 & -2.39 & -0.105 & -0.61 & -0.230 & -2.47 & -0.348 & -1.79 & 0.127 & 1.34 \\
\hline & $\mathrm{R}$ & 0 & 0 & 0 & 0 & 0 & 0 & 0 & 0 & 0 & 0 & 0 & 0 & 0 & 0 \\
\hline & Toplam & & -81.81 & & -1.20 & & -6.05 & & -0.87 & & -4.51 & & -3.71 & & 2.67 \\
\hline \multirow{5}{*}{ III } & A1 & -0.109 & -26.58 & -0.026 & -1.53 & -0.128 & -2.34 & -0.144 & -1.34 & -0.159 & -2.10 & -0.177 & -1.30 & -0.040 & -0.72 \\
\hline & $\mathrm{A} 2$ & -0.080 & -25.81 & 0.001 & 0.08 & -0.115 & -2.78 & -0.115 & -1.42 & -0.099 & -1.73 & -0.167 & -1.63 & -0.019 & -0.45 \\
\hline & A3 & -0.095 & -44.59 & -0.058 & -6.06 & -0.127 & -4.11 & -0.094 & -1.55 & -0.110 & -2.57 & -0.156 & -2.03 & -0.065 & -1.39 \\
\hline & C1 & 0 & 0 & 0 & 0 & 0 & 0 & 0 & 0 & 0 & 0 & 0 & 0 & 0 & 0 \\
\hline & Toplam & & -96.98 & & -7.51 & & -9.22 & & -4.31 & & -6.39 & & -4.96 & & -2.56 \\
\hline \multirow{5}{*}{ IV } & A1 & -0.121 & -13.75 & 0.048 & 1.30 & -0.057 & -0.47 & -0.003 & -0.01 & -0.867 & -5.33 & -0.293 & -1.01 & 0.269 & 1.90 \\
\hline & A2 & -0.062 & -35.09 & 0.103 & 15.04 & -0.020 & -0.90 & -0.017 & -0.35 & -0.855 & -28.41 & -0.244 & -4.54 & 0.263 & 10.05 \\
\hline & A3 & -0.005 & -1.90 & 0.000 & 0.00 & -0.069 & -2.08 & -0.113 & -1.56 & -0.857 & -19.11 & -0.072 & -0.90 & 0.012 & 0.31 \\
\hline & C1 & 0 & 0 & 0 & 0 & 0 & 0 & 0 & 0 & 0 & 0 & 0 & 0 & 0 & 0 \\
\hline & Toplam & & -13.78 & & 16.33 & & -3.46 & & -1.92 & & -52.84 & & -6.45 & & 12.26 \\
\hline
\end{tabular}


olmasına rağmen $\mathrm{Si}_{0} / \mathrm{Al}_{0}$ oranının da gösterdiği gibi allofan ve imogolit oluşumu için yeterli yoğunlukta gerçekleşmemiştir. Seçici çözelti ve FTIR (bu çalışmada verilmemiştir) analizleri de bu sonucu doğrulamaktadır. Profil 1 dışındaki tüm profillerde diğer bazik katyonlar düzenli negatif kütle taşınım değerleri göstermiştir. Bölgedeki kayaç çeşidinin bol miktarda Ca-Na feldspat (plajiyoklaz) ve ferromagnezyumlu mineraller içeren mafik karakterde olması sonucu söz konusu minerallerin ayrışması negatif değerlerin gözlenmesine neden olmuştur. Fe ve Al'daki negatif değerler de bu durumu açıklamaktadır. Ayrıca K, Fe, Mg'da saptanan negatif değerler mikaların çözünmesi ve biyotitin simektitlere ayrışması ile de açıklanabilir. Bazaltik kayaçlarda bulunan plajiyoklazlar çerçeve silikat olmalarına rağmen zamanla kolayca ayrışabilirler. Bu minerallerde bulunan alkali katyonlar ikincil kil minerallerinin yapısına girmemesi ve değişebilir formda zayıf tutulmaları nedeniyle kolayca yıkanırlar. $\mathrm{Ca}, \mathrm{Na}^{6} \mathrm{a}$ göre daha az net kayıp göstermiştir. Potasyum toprak oluşumunun başlangıç aşamalarında ayrışmaya oldukça duyarlıdır. Çalışma alanında K kayıpları \% 35'lere kadar çıkmıştır. Çalışılan alanlarda bitki örtüsünün çok yoğun olmaması, orman vejetasyonunun zayıf olması, yüzey horizonlarında da biyolojik döngü nedeniyle pozitif kütle taşınımı değerlerinin oluşumunu engellemiştir. Al ve $\mathrm{Fe}$ 'in diğer bazik katyonlara göre daha düşük negatif değerler göstermesi, bu katyonların kum fraksiyonundan seskioksit ve kil fraksiyonunda yeniden oryantasyonu ve böylece daha stabil bir hale dönüşmesi nedeniyle gerçekleşmiştir.

\section{Sonuç}

Çalışma alanında, açılan toprak profillerinde Nesbitt ve Young, (1982)'ın yapmış olduğu CIA sınıf değerlerine göre düşük ayrışma oranları bulunmuştur. Profillerin yamaç yüksek eğimli alanlarda bulunması nedeniyle toprak oluşumu erozyon nedeniyle olumsuz etkilenmiştir. Toprak erozyonu ve kitle hareketi veya toprak kaymaları, dağlık arazide önemli jeomorfik süreçlerdir. $\mathrm{Bu}$ süreçler toprak oluşumunu akamete uğratma potansiyeline sahiptir. Bu kesinti, özellikle yüksek eğim derecesinde nispeten yaygındır. Bu nedenle bu topraklar genç topraklar olarak tanımlanabilir. Araştıra bulguları çalışma alanında topoğrafik koşulların ve yetersiz ayrışma sürecinin toprağın fiziksel-kimyasal, mineralojik ve morfolojik özelliklerini doğrudan veya dolaylı olarak güçlü bir şekilde etkilediğini ortaya koymuştur.

Pedonlardaki fiziksel, kimyasal ve mineralojik özelliklerin benzer ve sınırlı varyasyona sahip olması ve jeokimyasal özellikler kullanılarak belirlenen ayrışma indekslerinin ve kütle kayıp modelinin pedonlar boyunca çok sınırlı bir varyasyon göstermesi, pedonların benzer ayrışma seviyelerine sahip olduğunu göstermektedir. Çalışmada kütle dengesi modeli kullanılarak toprak oluşumu süresi boyunca çeşitli elementler için kayıp ve kazanç durumları ortaya konmuştur. Profil 1 dışında kütle fonksiyonu tüm katyonlar için negatif çıkmıştır. Profil 1' de görülen pozitif kütle taşınım fonksiyonu ise, muhtemelen çevredeki yüksek arazilerden gelen silika ve diğer katyonlarca zengin sulardan kaynaklanmıştır.

Elde edilen verilerden ayrışma indisleri ve kütle taşınım fonksiyonlarının toprak oluşumunun sayısallaştırılmasında kullanılabileceği görülmüştür. Türkiye'deki volkanik ana materyaller üzerinde oluşan topraklar hakkında daha çok bilgiye ihtiyaç duyulmaktadır. Türkiye'nin değişik bölgelerine dağılmış ve volkanik ana materyal üzerinde oluşan toprakların özellikleri bölgesel kontrollerle aydınlatılmalıdır. Ayrıca yaşları iyi belirlenmiş yeterli sayıda toprak profiline dayanan ardışık zamanlı ve diğer sequenslere ait toprak oluşum süreçlerinin karşılaştırılması konusunda Türkiye'de yeterli çalışma bulunamamaktadır. Bu konuda jeokimyasal belirteçler kullanılarak yapılacak çalışmaların bölgemizde toprak oluşum süreçlerinin anlaşılmasındaki önemi dikkate alınarak geliştirilmesi önerilmiştir.

\section{Teşekkür}

Bu çalışma, TOVAG $110 \mathrm{O} 301$ nolu proje ile TÜBİTAK tarafından desteklenmiştir.

\section{Kaynaklar}

Anonim, 1962, Maden Tetkik Arama Genel Müdürlügü Türkiye Jeoloji Haritası.

Aydar, A., Gourgaud, A.,1998, The Geology of Mount Hasan Stratovolcano, Central Anatolia, Turkey, Journal of Volcanology and Geothermal Research, V: 85, Elseiver Science B.V., Page: 129-152.

Birkeland, P.W., 1999. Soils and Geomorphology, 3rd ed. Oxford Univ. Press, New York.

Blake, G. R., Hartge, K. H., 1986. Bulk Density. in: Klute, A., (Ed.), Methods of Soil Analysis, Part 1. Physical and Mineralogical Methods. Agronomy Monograph No: 9. SSSA, Madison, WI, Pp. 363-375. ( S: 393).

Bouyoucous, G. J., 1951, Recalibration of the Hydrometer Method for Making Mechanical Analysis of Soils. Agron, 43 (434-438).

Bricker SB, Ferreira JG, Simas T (2003) An integrated methodology for assessment of estuarine trophig, status. Ecol Modelling 169:39-60 
Brimhall, G.H. \& Dietrich, W.E., 1987. Constitutive mass balance relations between chemical composition, volume, density, porosity, and strain in metasomatic hydrochemical systems: Results on weathering and pedogenesis. Geochimica et Cosmochimica Acta 51, 567-587

Brimhall, G.H., Chadwick, O.A., Lewis, C.J., Compston, W., Williams, I.S., Danti, K.J.,Dietrich, W.E., Power, M.E., Hendricks, D.,Bratt, J., 1991a, Deformational mass transport and invasive processes in soil evolution. Science 255, 695-702.

Brimhall, G.H., Lewis, C.J., Ague, J.J., Dietrich, W.E., Hampel, J., Teague, T., Rix, P.,1988, Metal enrichment in bauxites by deposition of chemically mature aeolian dust. Nature 333(30), 819-824.

Brimhall, G.H., Lewis, C.J., Ford, C., Bratt, J., Taylor, G., Warin, O., 1991b, Quantitative geochemical approach to pedogenesis: importance of parent material reduction, volumetric expansion, and eolian influx in laterization. Geoderma 51, 51-91.

Brimhall, G.H.,Dietrich, W.E., 1987, Constitutive mass balance relations between chemical composition, volume, density, porosity, and strain in metasomatic hydrochemical systems: Results on weathering and pedogenesis. Geochimica et Cosmochimica Acta 51, 567-587.

Carr, R.G., Rodgers, K.A., Black, P.M., 1980. The chemical and mineralogical changes accompanying the laterization of basalt at Kerikeri, North Auckland. J. R. Soc. N.Z. 10, 247-258.

Chadwick, O.A., Brimhall, G.H., Hendricks, D.M., 1990, From ablack to a gray box-a mass balance interpretation of pedogenesis. Geomorphology 3, 369-390.

Chao, T. T., Sanzolone, R.F., 1992, Decomposition Techniques. Journal of Geochemical Exploration. 106 (44-65).

Chesworth, W., Dejou, J., Larroque, P., 1981. The weathering of basalt and relative mobilities of the major elements at Belbex, France. Geochim. Cosmochim. Acta 45, 1235- 1243

Egli, M. \& Fitze, P., 2000. Formulation of pedologic mass balance based on immobile elements: a revision. Soil Science 165, 437-443.

Emre, Ö., 1991, Hasan Dagı-Keçiboyduran Dag1 Yöresi Volkanizmasının Jeomorfolojisi, İ.Ü. Deniz Bilimleri ve Cografya Enstitüsü Doktora Tezi, (Yayınlanmamıs), İstanbul, Shf: 1-198.

Fedo, C.M., Nesbitt, H.W., Young, G.M., 1995. Unraveling the effects of potassium metasomatism in sedimentary rocks and paleosols, with implications for paleoweathering conditions and provenance. Geology 23, 921- 924.

Harden, J.W., 1988, Genetic interpretations of elemental and chemical differences in a soil chronosequence, California, Geoderma 43, 179-193

Harnois, L., 1988, The CIW index: a new Chemical Index of Weathering. Sedimentary Geology 55, 319- 322.

Hızalan, E., Ünalan, H., 1966. Toprakta Önemli Kimyasal Analizler. A. Ü. Ziraat Fakültesi Yayınları 278.

Hocaoğlu, Ö. L., 1970, Diyarbakır, Erzurum, Rize Bölgelerinde Bazalt Kayalarından Oluşan Topraklardaki Kil Mineralleri Üzerinde Bir Araştırma. Atatürk Üniversitesi Ziraat Fakültesi No 33.

Jenkins D A, Jones R G W., (1980). Traceelements in rock, soil, plantandanimal: introduction. In: Davies, B.E. (Ed.), AppliedSoilTraceElements. John Wileyand Son Ltd.,pp. 1-20.

Jenny, H., 1941, Factors of Soil Formation. McGraw-Hill, Newyork, Pp:281.

Ketin, İ., 1983, Türkiye Jeolojisine Genel Bir Bakiş Istanbul teknik üniversitesi yayınları $595 \mathrm{~s}$.

Langley-Turnbaugh, S.J. \& Bockheim, J.G., 1998. Mass balance of soil evolution on late Quaternary marine terraces in coastal Oregon. Geoderma 84, 265-288

Nieuwenhuyse, A. \& van Breemen, N., 1997. Quantitative aspects of weathering and neoformation in selected Costa Rican volcanic soils. Journal of the Soil Science Society of America 61, 1450-1458

Marshall, C.E., Haseman, J.F., 1942, The quantitativeevaluation of soil formation and development by heavy mineral studies: a Grundy silt loam profile. Soil Sci. Soc. Am. Proc. 7, 448-453.

McLennan, S.M., Hemming, S., McDaniel, D.K., Hanson, G.N., 1993.Geochemical approach to sedimentation, provenance, and tectonics. Spec. Pap.-Geol. Soc. Am. 284, 21-40.

Merritts, D.J., Chadwick, O.A., Hendricks, D.M., Brimhall, G.H., Lewis, C.J., 1992, The mass balance of soil evolution on late Quaternary marine terraces, northern California. GSA Bulletin 104, 1456-1470.

Nesbitt, H.W., 1979. Mobility and fractionation of rare earth elements during weathering of a granodiorite. Nature 279, 206- 210.

Nesbitt, H.W., Wilson, R.E., 1992. Recent chemical weathering of basalt. Am. J. Sci. 292, 740- 777

Nesbitt, H.W., Young, G.M., 1982. Early Proterozoic climates and plate motions inferred from major element chemistry of lutites. Nature 299, 715 -7 17

Nesbitt, H.W., Young, G.M., 1982. Early Proterozoic climates and plate motions inferred from major element chemistry of lutites. Nature 299 (5885), 715-717.

Nesbitt, H.W., Young, G.M., 1989. Formation and diagenesis of weathering profiles. J. Geol. 97, 129-147.

Owens, L.B., Watson, J.P., 1979. Rate of weathering and soil formation on granite in Rhodesia, Soil Sci. Soc. Am. J., 43" 160-166. 
Pasquare, G., 1966. Outtlines of the Neogene and Quaternary volcanism of Asia Minor. Accad. Naz. Dei Linc., 40, 1077-1085.

Reiche, R. 1950. A Survey of weathering Processes and Products. University of New Mexico Publication in Geology. The University of New Mexico Press. Soil Science: 123p 400-408

Soil Survey Laboratory Methods Manual, 2004. United States Department of Agriculture Natural Resources Conservation Service, Soil Survey Investigations, Report No. 42.

Soil Survey Manual, 1993. Soil Survey Manual. USDA Handbokk, No 18

Soil Survey Staff.,1999. Soil Taxonomy. A Basic System of Soil Classification for Making and interpreting Soil Survey. USDA agriculture Handbook Washington D.C. No: 436

Sutton, S. J., Maynard J. B. 1992. Multiple alteration events in the history of a sub-Huronian regolith at Lauzon Bay, Ontario Canadian Journal of Earth Sciences 29,432-445

Wakatsuki, T., Rasyidin, A., 1992. Rates of weathering and soil formation. Geoderma, 52 (1992) 251-263

U.S. Salinity lab. Staff, 1954. Diagnesis and Improvement of Saline and Alkali Soils. Agricultural Handbook., No 60 USDA.

White, A.F., 1983. Surface chemistry and dissolution kinetic of glassy rocks. Geochim. Cosmochim. Acta 47, 805816.

White, A.F., 1995. Chemical weathering rates of silicate minerals in soils. In: White, A.F., Brantley, S.L. (Eds)., Chemical Waethering Rates of Silicate Minerals. Reviews in Mineralogy, vol. 31, Mineralogical Society of America, pp. 407-461 